\title{
Dietary uptake of Green Fluorescent Protein for Delivery of dsRNA to Induce RNA Interference
}

\author{
Kathy La Fauce* and Leigh Owens \\ School of Veterinary and Biomedical Sciences, James Cook University, Townsville, QLD, 4811, Australia
}

\begin{abstract}
Double stranded RNA (dsRNA) is a potent initiator of the RNA interference (RNAi) pathways in a diverse range of organisms including plants, invertebrates and vertebrates. RNAi is increasingly being investigated as an antiviral mechanism, but often the research is hampered by the safe and cost effective delivery of the dsRNA to the target cells. This study uses specifically designed $E$. coli-expressed plasmids containing green fluorescent protein ( $g f p$ ), to determine if the plasmids still inside the bacterial cells can be successfully incorporated into host cells of the house cricket (Acheta domesticus), following ingestion of feed or water. This approach was trialled to determine, if using similar designed plasmids containing siRNAs can be effectively administered and provide protection against a target pathogen. Daily exposure through feed is the most effective for gfp expression (78\%-91.8\%) in A. domesticus, although weekly exposure was statistically equivalent and almost as good (75\%-99.9\%). Exposure via water gave reasonable uptake either daily or weekly $(60 \%-84 \%, 14 \%-56 \%$, respectively), but intensity was reduced and muscles did not demonstrate uptake $(\mathrm{P}<0.002)$. Continual or semi-continual exposure to gfp expressing bacteria resulted in increased uptake within cricket tissues, and increasing fluorescence (+++) with increasing exposure. Plasmid-based delivery via bacterial cells is therefore, an effective delivery tool and incorporation into feed allows a cost-effective method of providing continuous exposure for therapeutic purposes.
\end{abstract}

Keywords: RNA interference; Bacterially expressed dsRNA; Delivery; Green fluorescent protein

\section{Introduction}

RNA interference (RNAi) is post-transcriptional gene silencing triggered by double-stranded RNA (dsRNA) [1-4]. At least, six types of dsRNA have proven to be effective to various degrees [5-10]. However, short-interfering RNAs (siRNAs) (double stranded RNA, 21-22 nucleotides in length that promote gene silencing through the cleavage of mRNAs with exact complementary sequences) tend to produce the greatest silencing (often with the least toxicity) [11], and have therefore been the primary means for inducing RNAi-based gene silencing.

One of the challenges facing the application of RNAi in vivo is cheap, safe and cost effective delivery of the dsRNA, and its incorporation into the cells and spread between tissues. Numerous in vivo delivery strategies exist, ranging from the simple local delivery of 'naked' siRNA duplexes to the more complicated methods involving the systemic delivery of siRNA complexes as conjugates, liposome/ lipoplexes, as complexes with peptides, polymers including chitosan nanoparticles, antibodies or vector mediated. Vectors used in DNAbased technology can be broadly categorised as those derived from viruses [12], and those that are not (e.g. plasmids) [13,14]. Viral vectors take advantage of the facile integration of the gene of interest into the host cell and high probability of its long-term expression, but are plagued by safety concerns including toxicity and mutagenesis. Nonviral vectors, although less efficient in delivering DNA and in initiating and maintaining foreign gene expression and lacking specificity, are non-pathogenic and amenable to large scale production. Ideally, a gene-transfer vector should have the properties from viral and nonviral vectors including high transfection efficiency, convenience and reproducibility of production, ability to target the desired cell type and be non-pathogenic to the host.

Viral infections are one of the major constraints to aquaculture production and have led to significant economic losses within aquaculture, particularly regarding the culture of crustaceans.
Whilst large losses have been recorded due to white spot syndrome virus, yellowhead virus and taura syndrome virus, viral diseases in Australia continue to impede farming crustacean, with losses largely indirect through production losses rather than direct mortality, such as in densovirus infections in penaeids [15]. Like all invertebrates, crustaceans lack the vertebrate protective antibody immune response and therefore, cannot be effectively vaccinated against viral pathogens. Hence, the introduction of RNA interference as protective based immunity in crustacean production may serve as an effective control and preventative application for aquaculture.

Our previous work has involved the knockdown of the replication of Penaeus merguiensis densovirus (from the banana prawn, Penaeus merguiensis), following injection of dsRNA corresponding to the capsid protein. However, for large scale production and at the farm level, injecting every animal is time consuming and costly; simply not feasible. Hence, a more efficient delivery method needs to be developed for the efficient and cost-effective delivery of dsRNA for cost-effective large scale applications, such as aquaculture. Here we investigate a feeding model for the delivery of dsRNA and investigate cellular spread and its incorporation into host cells. We also compare the efficiency of $g f p$ uptake in crickets via a manufactured feed compared to exposure through water.

*Corresponding author: Kathy La Fauce, School of Veterinary and Biomedical Sciences, James Cook University, Townsville, QLD, 4811, Australia, E-mail: Kathy.lafauce1@jcu.edu.au

Received August 10, 2012; Accepted October 23, 2012; Published October 28 2012

Citation: Fauce KL, Owens L (2012) Dietary uptake of Green Fluorescent Protein for Delivery of dsRNA to Induce RNA Interference. J Marine Sci Res Dev 2:114. doi:10.4172/2155-9910.1000114

Copyright: @ 2012 Fauce KL, et al. This is an open-access article distributed unde the terms of the Creative Commons Attribution License, which permits unrestricted use, distribution, and reproduction in any medium, provided the original author and source are credited. 


\section{Materials and Methods}

\section{Insects}

Adult Acheta domesticus (house cricket) was purchased from Livefoods Unlimited (Queensland, Australia). Acheta domesticus was housed in plastic aquaria and provided with high protein dried dog food and fresh carrots (water source) ad libitum.

\section{Plasmids}

DNA encoding green fluorescent protein $(g f p)$ was synthesised chemically and subcloned into plasmid pJepress607 (DNA.2.0, USA). Plasmid containing $g f p$ was transformed into Escherichia coli JM109 cells, using pGEM-T Easy Vector Systems (Promega, Australia), according to the manufacturer's instructions. Four colonies were selected for screening of recombinant plasmids. Colonies were seeded into $10 \mathrm{ml}$ Luria Bertani (LB) medium supplemented with $100 \mathrm{mg} /$ $\mathrm{ml}$ hygromycin in a shaking incubator at $150 \mathrm{rpm}$ overnight at $37^{\circ} \mathrm{C}$. Recombinant plasmids were purified from bacteria using Wizard ${ }^{\circledR} \mathrm{Plus}$ SV Minipreps DNA purification system (Promega, Australia), according to the manufacturer's instructions. Recombinant plasmids were electrophoresed on $1 \%$ agarose gel containing gel red, to screen for recombinant plasmids containing $g f p$.

\section{Confirmation of bacterially expressed plasmids}

Escherichia coli bacterially expressed plasmids were extracted according to the protocol of Wizard plus SV Minipreps DNA Purification System (Promega, Australia). Plasmid DNA was quantified by spectrophotometry run on a $1 \%$ agarose gel containing gel red. A 100 bp plus ladder (MBI Fermentas) was used as a DNA marker to determine the size of recombinant plasmids. Plasmids were viewed and photographed under ultraviolet light, using Gel-Doc (Bio-Rad, Australia).

\section{Experimental design}

Acheta domesticus was randomly distributed between seven experimental treatments (Table 1). Each treatment contained three replicates of ten animals. Animals were monitored daily and deceased animals were removed and recorded. Deceased animals were immediately prepared for fluorescent microscopy. The experimental period began on Day 1 and concluded on Day 30, or until animals in experimental treatments died. Following the conclusion of the experimental period, all remaining animals were sacrificed and immediately prepared for fluorescent microscopy.

\section{Preparation of bacteria}

To express dsRNA in E. coli for incorporation into their food pellets, bacteria containing recombinant $g f p$ plasmid were cultured in LB broth supplemented with $100 \mathrm{mg} / \mathrm{ml}$ hygromycin at $37^{\circ} \mathrm{C}$ in a shaking incubator at $150 \mathrm{rpm}$, until the optical density $\left(\mathrm{OD}_{600}\right)$ reached

\begin{tabular}{|l|c|c|}
\hline $\begin{array}{l}\text { Treatment (three repli- } \\
\text { cates of } \mathbf{1 0} \text { crickets) }\end{array}$ & Exposure to GFP & $\begin{array}{c}\text { Day of experiment of } \\
\text { exposure }\end{array}$ \\
\hline Unhandled controls & N/A & N/A \\
\hline F1 & Food & Day 1 only \\
\hline F2 & Food & Day 1,7 and 14 \\
\hline F3 & Food & Daily \\
\hline W1 & Water & Day 1 only \\
\hline W2 & Water & Day 1,7 and 14 \\
\hline W3 & Water & Daily \\
\hline
\end{tabular}

Table 1: Experimental design for exposure of the house cricket (Acheta domesticus) to $g f p$ expressed plasmids in Escherichia coli.
1.0 at which time the bacteria were harvested. $10 \mathrm{ml}$ of bacteria for each feed replicate were collected by centrifugation at $4500 \mathrm{~g}$ for 10 minutes at room temperature, using Eppendorf centrifuge 5804 (Eppendorf, Germany). Bacterial pellets were resuspended in $500 \mathrm{ml}$ of sterile water and re-pelleted by centrifugation at $4500 \mathrm{~g}$ for 10 minutes at room temperature. This was repeated twice to wash the bacterial pellet and remove traces of antibiotic from the media. Following the final centrifugation, the washed bacterial pellet was resuspended in just enough sterile water to suspend and collect the bacterial pellet.

\section{Incorporation of bacteria into feed}

Acheta domesticus were supplied with fresh feed daily containing either no E. coli or E. coli expressing gfp. Crickets were starved and held without water, 24 hours prior to their initial exposure. Afterwards, at no time during the experimentation with feed were the crickets depleted of food. Bacteria prepared above were mixed in equal amounts of crushed dry dog food. The bacterial/food preparation was subsequently freeze dried until a soft pellet had formed, and was immediately placed in the appropriate experimental treatments.

\section{Incorporation of bacteria into water}

Acheta domesticus were starved and held without water 24 hours prior to their initial exposure. Subsequently, crickets were supplied with fresh water daily, containing either no E. coli or E. coli expressing gfp. Bacterial pellets were prepared as described above, and the washed resuspended bacterial pellet was mixed 50:50 with sterile water and immediately placed in the appropriate experimental treatment. At no time during the administration of water were the animals depleted of water.

\section{Fluorescent microscopy}

Acheta domesticus were prepared for fluorescent microscopy by placing in $10 \%$ buffered neutral formalin for 24 hours. Formalin was also injected into the body of all crickets to ensure internal tissues were appropriately fixed. All injections were performed using sterile Terumo (1ml) syringes with a 26-gauge needle by inserting the needle into the membrane below the pronotum. After 24 hours, the head and legs were removed and the body was split longitudinally to obtain the appropriate sections of the tissues for fluorescent microscopy. Tissues were placed into the appropriately labelled cassettes and transferred to $70 \%$ ethanol and processed routinely for histology, before being imbedded in paraffin wax. Sections were cut at $5 \mu \mathrm{m}$ and taken through a series of grades of xylene and ethanol to remove the paraffin wax from sections. Slides were kept out of direct sunlight and stored at $4^{\circ} \mathrm{C}$ until required for fluorescent microscopy. Images were acquired using AxioVision three-channel Multichannel Fluorescence (Carl Zeiss Fluorescent Microscope). Channels were configured for the fluorochromes FITC (fluorescein isothiocyanate), DAPI (4'6-diamidino-2phenylindole) and TR (Texas red or sulforhodamine 101 acid chloride). All tissues were examined for uptake of $g f p$. Of particular interest was the exoskeleton, muscle and proventriculus tissue, since these tissues were guaranteed to be observed in cricket sections. Results were graded on brightness of fluorescence.

\section{Statistical Analysis}

All analyses were conducted using IBM Statistical Program for the Social Sciences (SPSS, IBM Corporation v 20). Data was coded as follows: no green fluorescence (perhaps grey to pale blue) $=0$ (Figure $1 \mathrm{~A}$ ), pale green fluorescence $+=1$ (Figure $1 \mathrm{~B}$ ), green fluorescence $++=2$ (Figure 1C), bright green fluorescence $+++=3$ (Figure 1D). The 

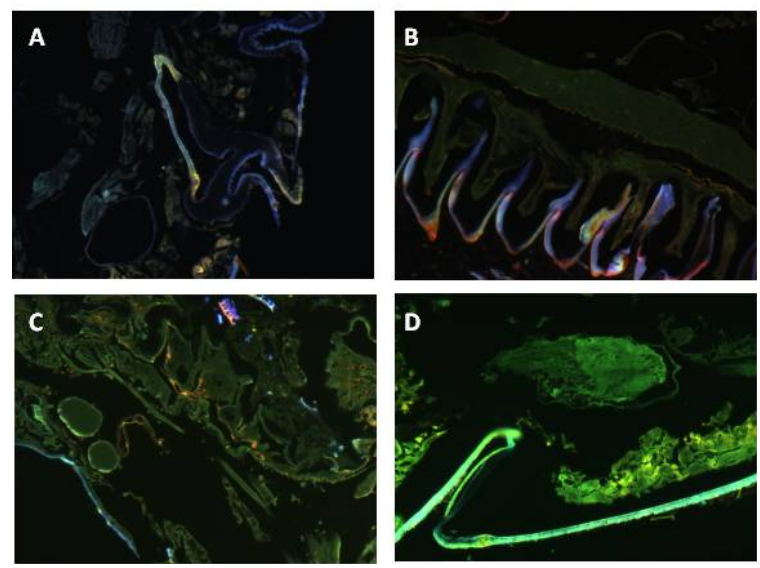

Figure 1: Grading of fluorescence of Acheta domesticus tissues using fluorescent microscopy (A) Muscle and exoskeleton (-); (B) Proventriculus (+); (C) Exoskeleton and muscle (++); (D) Exoskeleton and muscle $(+++)$

\begin{tabular}{|c|c|c|c|c|}
\hline Treatment & Exoskeleton & Muscle & Proventriculus & $\begin{array}{l}\text { Proventriculus as- } \\
\text { sociated tissues }\end{array}$ \\
\hline \multirow[t]{3}{*}{ Unhandled controls } & $0 \%(+++)$ & $0 \%(+++)$ & $0 \%(+++)$ & $0 \%(+++)$ \\
\hline & $0 \%(++)$ & $0 \%(++)$ & $0 \%(++)$ & $0 \%(++)$ \\
\hline & $0 \%(+)$ & $0 \%(+)$ & $0 \%(+)$ & $0 \%(+)$ \\
\hline Total & $0 \%$ & $0 \%$ & $0 \%$ & $0 \%$ \\
\hline \multirow[t]{3}{*}{ Food-Day 1} & $0 \%(+++)$ & $0 \%(+++)$ & $0 \%(+++)$ & $0 \%(+++)$ \\
\hline & $0 \%(++)$ & $20 \%(++)$ & $40 \%(++)$ & $20 \%(++)$ \\
\hline & $0 \%(+)$ & $0 \%(+)$ & $20 \%(+)$ & $0 \%(+)$ \\
\hline Total & $0 \%$ & $20 \%$ & $60 \%$ & $20 \%$ \\
\hline \multirow[t]{3}{*}{ Food-Day 1, 7, 14} & $0 \%(+++)$ & $50 \%(+++)$ & $50 \%(+++)$ & $66.6 \%(+++)$ \\
\hline & $0 \%(++)$ & $0 \%(++)$ & $12.5 \%(++)$ & $33.3 \%(++)$ \\
\hline & $0 \%(+)$ & $25 \%(+)$ & $25 \%(+)$ & $0 \%(+)$ \\
\hline Total & $0 \%$ & $75 \%$ & $87.5 \%$ & $99.9 \%$ \\
\hline \multirow[t]{3}{*}{ Food-Daily } & $33 \%(+++)$ & $28 \%(+++)$ & $53.8 \%(+++)$ & $38.4 \%(+++)$ \\
\hline & $0 \%(++)$ & $7 \%(++)$ & $23 \%(++)$ & $38.4 \%(++)$ \\
\hline & $0 \%(+)$ & $43 \%(+)$ & $15 \%(+)$ & $15 \%(+)$ \\
\hline Total & $33 \%$ & $78 \%$ & $91.8 \%$ & $91.8 \%$ \\
\hline \multirow[t]{3}{*}{ Water-Day 1} & $10 \%(+++)$ & $10 \%(+++)$ & $12.5 \%(+++)$ & $28 \%(+++)$ \\
\hline & $0 \%(++)$ & $0 \%(++)$ & $50 \%(++)$ & $28 \%(++)$ \\
\hline & $0 \%(+)$ & $40 \%(+)$ & $12.5 \%(+)$ & $28 \%(++)$ \\
\hline Total & $10 \%$ & $50 \%$ & $75 \%$ & $84 \%$ \\
\hline \multirow[t]{3}{*}{ Water-Day $1,7,14$} & $0 \%(+++)$ & $0 \%(+++)$ & $28 \%(+++)$ & $0 \%(+++)$ \\
\hline & $0 \%(++)$ & $0 \%(++)$ & $0 \%(++)$ & $14 \%(++)$ \\
\hline & $0 \%(+++)$ & $0 \%(+)$ & $28 \%(+)$ & $0 \%(+)$ \\
\hline Total & $0 \%$ & $0 \%$ & $56 \%$ & $14 \%$ \\
\hline \multirow[t]{3}{*}{ Water-Daily } & $0 \%(+++)$ & $0 \%(+++)$ & $42 \%(+++)$ & $20 \%(+++)$ \\
\hline & $0 \%(++)$ & $0 \%(++)$ & $28 \%(++)$ & $0 \%(++)$ \\
\hline & $0 \%(+)$ & $0 \%(+)$ & $14 \%(+)$ & $40 \%(+)$ \\
\hline Total & $0 \%$ & $0 \%$ & $84 \%$ & $60 \%$ \\
\hline
\end{tabular}

+++ Bright fluorescence

++ Medium fluorescence

+ Low fluorescence

*Percentage is based on the number of crickets for which the tissues could be analysed. In some circumstances, one or two of the above tissues may have been absent from the cricket sections due to the processing and angle of cutting of the longitudinal section of the cricket.

Table 2: Summary of Acheta domesticus tissues exhibiting fluorescence following exposure to bacterially expressed gfp via food or water (grading of fluorescence is represented in Figure 1$)^{*}$

data were tested for Normality using Q-Q plots and failed. Therefore, nonparametric statistics were used throughout. A Kruskal-Wallis
ANOVA for independent samples was used to find differences across the treatments, and then a Mann Witney $\mathrm{U}$ test was used to test fluorescent levels in individual tissues within treatments. As many repeated comparisons were made, the probability of a type I error increased, so a conservative approach was taken and only those treatments that differed at $\mathrm{P}<0.01$ level were considered significant.

\section{Results}

\section{Fluorescent microscopy}

Food source: There was no significant fluorescence in the exoskeleton of GFP plasmid-exposed crickets over the non-exposed controls (lowest $\mathrm{P}=0.124$ ). Excluding the exoskeleton, cellular uptake of $g f p$ following delivery via food of bacterially expressed $g f p$ was most common, following multiple exposures to feed containing bacterially expressed GFP (78-91.8\%) (Table 2). Following exposure on Day 1, fluorescence was primarily observed in proventriculus tissues, with only $20 \%$ of crickets exhibiting $g f p$ uptake in muscle or proventriculus associated tissues.

Food exposure on Day 1, 7 and 14 resulted in an increase in the percentage of crickets, with fluorescence observed in proventriculus tissue and in the muscle, and the intensity of fluorescence over those crickets fed on Day 1 only. Fluorescence was observed in over $87.5 \%$ of proventriculus tissue, $75 \%$ of muscle, and over $50 \%$ of each of these tissues exhibited a strong green fluorescence. However, no fluorescence was observed in the exoskeleton of any crickets.

Fluorescence was observed in the exoskeleton of crickets $(33 \%)$ only following daily feed exposure to bacterially expressed $g f p$. The greatest number of cricket tissues exhibiting fluorescence was greatest in tissues from crickets exposed daily to bacterially expressed $g f p$. Fluorescence was observed in over $90 \%$ of proventriculus tissues, $78 \%$ of muscle tissue and $33 \%$ of cricket exoskeletons.

In terms of intensity with food delivery, GFP significantly increased over the controls in the muscle, proventriculus and proventriculusassociated tissues in crickets fed daily $(\mathrm{P}<0.0001)$ and weekly (days 1,7 , 14) $(\mathrm{P}<0.0001-0.001)$, but not those fed only once (day 1$)$.

\section{Water source}

Fluorescence was only observed in the exoskeleton and muscle of crickets exposed to bacterially expressed $g f p$ via the water source exposed on Day 1 of the experiment. Whilst over $75 \%$ of cricket proventriculus tissues exhibited fluorescence, fluorescence was weaker (mostly ++ , figure 1C) compared to tissues from crickets exposed via food source (mostly +++ , figure 1D).

Proventriculus tissue of $56 \%$ of crickets exposed to bacterially expressed $g f p$ via their water source on Day 1, 7 and 14 exhibited fluorescence, and only $14 \%$ of crickets had alternate tissues exhibit fluorescence.

In terms of intensity with water delivery, GFP was significantly increased over the controls in the proventriculus and proventriculusassociated tissues in crickets fed on day 1only $(\mathrm{P}<0.000)$ and daily $(\mathrm{P}<0.001)$, but not weekly (days $1,7,14)(\mathrm{P}>0.01)$. With weekly delivery of the GFP plasmid by water, the fluorescence failed to reach the muscle $(\mathrm{P}<0.002)$ and only just reached the proventriculus-associated tissue $(\mathrm{P}<0.01)$ of some crickets $(14 \%)$, which was significantly less when compared to daily delivery by food. Also, weekly delivery by water was significantly less than weekly delivery by food $(\mathrm{P}<0.009)$. Whilst some other comparisons reached the $\mathrm{P}<0.05$ but not the $\mathrm{P}<0.01$ level 
of significance, these comparisons are not considered robust enough to be discussed.

\section{Discussion}

Here we determine the bacteria, Escherichia coli containing recombinant plasmids containing $g f p$ with the appropriate promoters can be successfully delivered to cricket tissues either through water or feed. This study confirms the study of Rajeshkumar et al. [16] that food can deliver plasmids to arthropods, but is contradictory to the study of Sellars et al. [17] that found formalin killed bacterial cells could not deliver dsRNA. This study confirmed that incorporation into feed pellets is the most successful oral delivery into cricket tissues.

Daily exposure via water and feed resulted in the highest percentage of $g f p$ cell uptake. Interestingly, the percentage of tissues exhibiting fluorescence following exposure via water was highest after the initial exposure on Day 1 compared with three exposures on Day 1, 7, and 14. Crickets were starved and held without water 24 hours prior to their initial exposure, increasing the likelihood of the animals consuming the feed/water containing gfp on Day 1 of the experiment. This may suggest that dehydration may lead to higher uptake. Nevertheless, exposure via a food source resulted in greater percentages of tissues exhibiting fluorescence and a stronger fluorescence signal.

Fluorescence was most commonly observed in the proventriculus, followed by proventriculus-associated tissues, muscle and exoskeleton, respectively. This was a common pattern observed under increasing exposure frequency suggesting that crickets are consuming the bacteria. Presumably, the bacteria are ground up in the gut of the cricket so the cells of the gut-associated tissues are the first to absorb and incorporate the plasmid containing $g f p$ into their cells. With increasing exposure, the crickets consume more bacteria and eventually, cellular uptake extends to crossing the gut barrier and the plasmids are subsequently incorporated into the muscle cells and cells below the exoskeleton. Since the results have suggested plasmid uptake has crossed the gut wall barrier, it may also be assumed that it is also circulating systemically in the animal. Hence, the expression of bacterially expressed plasmids in specific cells or tissues may be dose dependent on the ingestion of bacterially expressed plasmids. Similar dose dependency of dsRNA has previously been reported in a number of arthropod species $[18,19]$ and in plants [20], but is not universal [4].

There was a lack of fluorescence observed in the oocytes and eggs of mature females, suggesting that it may not be passed onto progeny in the short term. Perhaps prolonged exposure may be required, or exposure is required before the animals become sexually mature. It could also suggest that not all cells are equally sensitive to dsRNA delivery by ingestion, and some cells or stages of development may be resistant to the effects of ingested dsRNA. Interestingly, there was no difference in $g f p$ uptake with respect to gender (data not shown).

This approach was trialled to determine if using similarly designed plasmids containing siRNAs can be effectively administered and provide protection against a target pathogen. It has been suggested by Timmons and Fire [21] bacterial mediated delivery of dsRNA is less effective than direct microinjection of the dsRNA. Similarly, Sellars et al. [17] report antiviral RNAi to gill associated virus is not readily induced in juvenile Penaeus monodon, when dsRNA was delivered orally. However, the oral administration of bacterially expressed dsRNA has proved to down regulate gene expression in a number of animals including arthropods [22,23] and planarians [24], and also to protect plants from viral pathogens [25].
La Fauce and Owens [26] previously determined that siRNAs delivered by injection, provided antiviral protection against Penaeus merguiensis densovirus in Acheta domesticus (animal model for penaeid prawns, La Fauce and Owens [27]). Unlike the previous studies regarding the delivery of bacterially expressed dsRNA, it has been determined and tracked the cellular uptake of $g f p$ throughout the animal to determine, if delivering dsRNA using a similar method would be successful in inducing the RNAi pathway.

In conclusion, it was confirmed for plasmid DNA in E. coli cells can be efficiently used to deliver plasmid-based siRNAs into cells via a feeding method. Delivery of dsRNA by feeding provides what could be a continuous, cost-effect method of delivery of dsRNA. Gfp was efficiently incorporated into the cells of the gut, muscle and those underlying the exoskeleton following repeated exposure to plasmidincorporated E. coli in feed. These findings revealed that given the appropriate promoters, plasmid based delivery vectors in bacteria are an effective delivery tool.

It is not yet known if this incorporation into cells via a feeding regime provides sufficient protection compared with the direct injection of siRNAs, how long the protection lasts, and if it can be passed onto progeny. Nevertheless, the findings in this study bring one step closer to providing large scale and cheap protection against pathogens, particularly those of viral origin. In the absence of a $\mathrm{B}$ cell lineage in arthropods, the introduction of using RNA interference in crustacea may serve as an effective control and preventative measure for viral diseases for application in aquaculture, where disease continues to be a major constraint to the industry.

\section{Acknowledgements} Fund.

This research was supported through the Australia-India Strategic Research

\section{References}

1. Hammond SM (2005) Dicing and slicing: the core machinery of the RNA interference pathway. FEBS Lett 579: 5822-5829.

2. Lingel A, Sattler M (2005) Novel modes of protein-RNA recognition in the RNA pathway. Curr Opin Struct Biol 15: 107-115

3. Dykxhoorn DM, Novina CD, Sharp PA (2003) Killing the messenger: short RNAS that silence gene expression. Nat Rev Mol Cell Biol 4: 457-467.

4. Fauce $\mathrm{KL}$, Owens $\mathrm{L}$ (2012) RNA interference with special reference to combating viruses of Crustacea. Indian J Virol 23: 226-243.

5. Yang D, Lu H, Erickson JW (2000) Evidence that processed small dsRNAs may mediate sequence-specific mRNA degradation during RNAi in Drosophila embryos. Curr Biol 10: 1191-1200.

6. Zamore PD, Tuschl T, Sharp PA, Bartel DP (2000) RNAi: Double-Stranded RNA directs the ATP-dependent cleavage of mRNA at 21 to 23 nucleotide intervals. Cell 101: 25-33.

7. Elbashir SM, Harborth J, Lendeckel W, Yalcin A, Weber K, et al. (2001) Duplexes of 21-nucleotide RNAs mediate RNA interference in cultured mammalian cells. Nature 411: 494-498.

8. Elbashir SM, Harborth J, Weber K, Tuschl T (2002) Analysis of gene function in somatic mammalian cells using small interfering RNAs. Methods 26: 199-213.

9. Paddison PJ, Caudy AA, Bernstein E, Hannon GJ, Conklin DS (2002) Short hairpin RNAs (shRNAs) induce sequence-specific silencing in mammalian cells. Genes Dev 16: 948-958.

10. Ambros V, Lee RC, Lavanway A, Williams PT, Jewell D (2003) MicroRNAs and other tiny endogenous RNAs in C.elegans. Curr Biol 13: 807-818.

11. Rao M, Baraban JH, Rajaii F, Sockanathan S (2004) In vivo comparative study of RNAi methodologies by in ovo electroporation in the chick embryo. Dev Dyn 231: $592-600$. 
Citation: Fauce KL, Owens L (2012) Dietary uptake of Green Fluorescent Protein for Delivery of dsRNA to Induce RNA Interference. J Marine Sci Res Dev 2:114. doi:10.4172/2155-9910.1000114

Page 5 of 5

12. Kay MA, Glorioso JC, Naldini L (2001) Viral vectors for gene therapy: the art of turning infectious agents into vehicles of therapeutics. Nat Med 7: 33-40

13. Liu F, Huang L (2002) Development of non-viral vectors for systemic gene delivery. J Control Release 78: 259-266.

14. Schmidt-Wolf GD, Schmidt-Wolf IG (2003) Non-viral and hybrid vectors in human gene therapy: an update. Trends Mol Med 9: 67-72.

15. Owens L, La Fauce K, Claydon K (2011) The effect of Penaeus merugiensis densovirus on Penaeus merguiensis production in Queensland, Australia. J Fish Dis 34: 509-515

16. Rajeshkumar S, Venkatesan C, Sarathi M, Sarathbabu V, Thomas J, et al. (2009) Oral delivery of DNA construct using chitosan nanoparticles to protect the shrimp from white spot syndrome virus (WSSV). Fish Shellfish Immuno 26: 429-437.

17. Sellars MJ, Rao M, Arnold SJ, Wade NM, Cowley JA (2011) Penaeus monodon is protected against gill-associated virus by muscle injection but not oral delivery of bacterially expressed dsRNAs. Dis Aquat Organ 95: 19-30.

18. Tian H, Peng H, Yao Q, Chen H, Xie Q, et al. (2009) Developmental control of a Lepidopteran pest Spodoptera exigua by ingestion of bacteria expressing dsRNA of a non-midgut gene. PLoS One 4: e6225.

19. Mohamed AA, Kim $Y$ (2011) A target-specific feeding toxicity of $\beta(1)$ integrin dsRNA against diamondback moth, Plutella xylostella. Arch Insect Biochem Physiol 78: 216-230.
20. Tenllado F, Martinez-Garcia B, Vargas M, Diaz-Ruiz JR (2003) Crude extracts of bacterially expressed dsRNA can be used to protect plants against virus infections. BMC Biotechnol 3: 3 .

21. Timmons L, Fire A (1998) Specific interference by ingested dsRNA. Nature 395: 854 .

22. Sarathi M, Simon MC, Venkatesan C, Hameed AS (2008) Oral administration of bacterially expressed VP28dsRNA to protect Penaeus monodon from white spot syndrome virus. Mar Biotechnol 10: 242-249.

23. Zhu F, Xu J, Palli R, Ferguson J, Palli SR (2011) Ingested RNA interference for managing the populations of the Colorado potato beetle, Leptinotarsa decemlineata. Pest Manag Sci 67: 175-182.

24. Newmark PA, Reddien PW, Cebria F, Sanchez Alvarado A (2003) Ingestion of bacterially expressed double-stranded RNA inhibits gene expression in planarians. Proc Natl Acad Sci U S A 100: 11861-11865.

25. Gan D, Zhang J, Jiang H, Jiang T, Zhu S, et al. (2010) Bacterially expressed dsRNA protects maize against SCMV infection. Plant Cell Rep 29: 1261-1268.

26. La Fauce KA, Owens L (2009) RNA interference reduces PmergDNV expression and replication in an in vivo cricket model. J Invertebr Pathol 100: $111-115$.

27. La Fauce KA, Owens L (2008) The use of insects as a bioassay for Penaeus merguiensis densovirus (PmergDNV). J Invertebr Pathol 98: 1-6.
Submit your next manuscript and get advantages of OMICS Group submissions

\section{Unique features:}

User friendly/feasible website-translation of your paper to 50 world's leading languages

Audio Version of published paper

Digital articles to share and explore

Special features:

200 Open Access Journals

15,000 editorial team

21 days rapid review process

Quality and quick editorial, review and publication processing

Indexing at PubMed (partial), Scopus, DOAJ, EBSCO, Index Copernicus and Google Scholar etc

Sharing Option: Social Networking Enabled

Authors, Reviewers and Editors rewarded with online Scientific Credits

Better discount for your subsequent articles

Submit your manuscript at: www.editorialmanager.com/environsci 